\title{
THE ARTERIAL BLOOD SUPPLY OF THE FOOT OF THE DOMESTICATED DUCKS (ANAS DOMESTICUS).
}

\author{
Farag, F.M.M.
}

Anatomy and embryology departement, Faculty of Veterinary Medicine, Cairo University

\begin{abstract}
The arterial supply of the foot was carried out on ten adult, healthy domestic ducks. The arteries were demonstrated by injection of colored gum milk latex and treated by the ordinary method of preserving. The arterial supply of the foot was achieved mainly by the cranial tibial artery. The foot received its arterial supply through two sets of arteries; dorsal and plantar. The dorsal set comprised the Rete tibiotarsale and A.metatarsea dorsalis communis. The plantar set of arteries supplying the foot was derived from Aa.tarseae plantares and the plantar arch. The digital arteries arose from the latter arch except those of the $2^{\text {nd }}$ digit and mostly the lateral artery of the $4^{\text {th }}$ digit.The metatarsal pad was supplied by single pulvinar branch arising from either the plantar arch or A. digitalis III lateralis. The interdigital web was supplied by fine transverse rami arising from the Aa.digitales III medialis and lateralis, A.digitalis II lateralis and A.digitalis IV medialis as well as a longitudinal branch arising from the latter artery. These rami were anastomosed forming capillary network distributed all over the web.
\end{abstract}

The results obtained were photographed, described and discussed with those of other studies in domestic birds.

Key words: Arterial supply- foot-domestic duck 


\section{INTRODUCTION}

The progress in the avian surgery increased the demand for more knowledge about the anatomy of the birds. Avian foot was subjected to many injuries; wounds, bumble foot, fibriscess swelling of the metatarsal pad were the most common and needed surgical interference (Heidenreich, 1997; Routh, 2000; Cooper, 2002). On reviewing the available literature there was not any adequate information about the arterial supply of this region in the duck. On the other hand the arterial supply of the pelvic limb in birds has been outlined by several authors, Mcleod et al. (1964), Koch (1973), Baumel (1975), Nickel et al. (1977) and El-Gammal (2012) in the domestic fowl, Fitzgerald (1969) in the coturnix quail, Midtgard (1981) and Dursun (2002) in the different domestic birds, Can et al. (2010) in the Japanese quail and El-Nahla et al.(2010) in the ostrich. Therefore, current study was performed to be highlight for the arterial vascularization of the foot of this bird as a model which may be helpful in surgical approach to this region in different avian breeds.

\section{MATERIAL AND METHODS}

The present work was carried out on ten healthy domestic ducks weighing about 2.5 to $3.5 \mathrm{~kg}$. Before exsanguinations, the ducks were anaesthetized by intramuscular injection of $0.5 \mathrm{cc}$ of $2 \%$ xylazine hydrochloride to ensure proper relaxation and avoid vasoconistriction, then injected with heparin (Cal Heparin, 5000 I.U. diluted by $1-2 \mathrm{~cm}$. saline solution) through the wing vein. 
Each specimen was exsanguinated through the common carotid arteries. The breast muscle and sternum were removed to expose the descending aorta through which a Nelaton catheter of size $8 \mathrm{~F}$ to $10 \mathrm{~F}$ was introduced just caudal to the heart. The injection approach comprised $60 \%$ latex neoprene coloured red with Rottring ink and the specimens were kept in $10 \%$ formaline, $4 \%$ phenol and $1 \%$ glycerine three days before dissection.

The nomenclature used in this study adopted after the Nomina Anatomica Avium (1993).

\section{RESULTS}

The arterial supply of the foot was comring from one main source , the cranial tibial artery (Fig.1/2) that represented the continuation of the popliteal artery (Fig.1/1) through the distal interosseous foramen (Fig.1/a) between the tibiotarsus (Fig.1/b) and fibula (Fig.1/ c). It descended along the cranial aspect of the tibiotarsus to its distal third where it detached 2-3 collateral branches that concurred in forming a vascular network called the Rete tibiotarsale after which it continued distally as the A. metatarsea dorsalis communis. The arterial architecture of the foot could be arranged into two sets; dorsal and plantar.

\section{I- The dorsal set:}

The dorsal set of arteries supplying the foot comprised the Rete tibiotarsale and A.metatarsea dorsalis communis.

\section{Rete tibiotarsale:}

The tibiotarsal rete (Fig.1, 2, 5 and 6/3) was formed of multiple parallel vessels namelly; the collateral branches arising from the distal 
third of the cranial tibial artery, deep fibular (Fig.1/5), superficial fibular (Fig.1/6) and lateral sural arteries (Fig.1/ 14 ) as well as some closely related veins. They branched and re-united with the axially oriented cranial tibial artery that continued distally beyond this rete as the common dorsal metatarsal artery.

\section{A.metatarsea dorsalis communis:}

The common dorsal metatarsal artery (Fig.2, 4, 5/7) constituted the distalward continuation of the cranial tibial artery after traversing the Rete tibiotarsale. It descended along the flexor surface of the tarsus, under the transverse ligaments of the tarsometatarsus. Joint on reaching the level of the proximal vascular foramen of the tarsometatarsus it gave of the Aa. Tarseae plantares and then divided into two branches; the medial and lateral dorsal metatarsal arteries.

\section{A.metatarsi dorsalis medialis:}

The medial dorsal metatarsal artery (Fig.2, 4, 5/ 8) was the smaller of the two vessels arisen from the A.metatarsea dorsalis communis. It descended along the dorsomedial aspect of the tarsometatarsus in accompany with the corresponding dorsal metatarsal nerve (Fig.4/r) and terminated just proximal to the metatarsophalangeal articulation of the $2^{\text {nd }}$ phalanx by dividing into the Aa.digitales II medialis and lateralis. Along its course it detached fine braches that supplied the the tendon of the M. extensor digitorum communis, M. extensor proprius digiti III and M. extensor hallucis longus.

\section{A.metatarsi dorsalis lateralis:}

The lateral dorsal metatarsal artery (Fig.2, 4, 5/9) represented the direct continuation of the A.metatarsea dorsalis communis. It descended

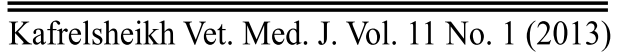


along the dorsal aspect of the tarsometatarsus in accompanied with the corresponding dorsal metatarsal nerve (Fig.4/ r) to the level of the distal vascular foramen (Fig.2, 3/h) of this bone; through which it passed to the plantar aspect and joined the plantar arch. Throughout its course the lateral dorsal metatarsal artery gave off branches supplying the tendon of the $\mathrm{M}$. extensor digitorum communis as well as $\mathrm{M}$. extensor proprius digiti III and Mm. extensor breves digiti III and IV.

\section{II- The plantar set:}

The plantar set of arteries supplying the foot was derived from Aa.tarseae plantares and the plantar arch.

\section{Aa.tarseae plantares:}

The medial (Fig.2,3/10) and lateral ( (Fig.3/11) plantar tarsal arteries were given off from common dorsal metatarsal artery at the level of the proximal vascular foramina (Fig.2, 3/f) of the tarsometatarsus. In eight specimens these two vessels originated by very short common stem vessel. Each of these vessels pierced through the corresponding proximal vascular foramen of the tarsometatarsus and gained the plantar aspect where it soon divided into two branches; an ascending and a descending branch. Both ascending branches; medial (Fig.2,3/12 ) and lateral (Fig.3/13) were extended proximally along the corresponding aspect of the tarsus, where it detaches fine articular branches to tarsometatarsus joint and cutaneous branches supplying the skin on either side of the joint and then anastomosed with the corresponding medial (Fig.1/ 15) arteries and lateral (Fig.1/ 16) branches of the A. suralis lateralis (Fig.1/14 ). The descending branches were extended distally as the plantar metatarsal arteries. 


\section{Aa.metatarseae plantares:}

The medial (Fig.2,3/17) and lateral (Fig.3/18) plantar metatarsal arteries represented the direct continuation of the corresponding plantar tarsal arteries on the sides of the plantar aspect of the tarsometatarsus. They extended distally, giving several small branches to the M. flexor hallucis longus and M. flexor digitorum longus as well as the tendon of the M. flexor digitorum profundus and M. flexor digitorum superficialis. The two vessels were connected through 1-2 transverse communicating branches (Fig.3/19) and terminated by joining the lateral dorsal metatarsal (after its emergence from the distal foramen of the tarsometatarsus) forming the plantar arch.

\section{Arcus plantaris:}

The plantar arch (Fig.3/20) was formed by the communication established between the plantar metatarsal arteries with the lateral dorsal metatarsal artery after its emergence from the distal foramen of the tarsometatarsus. It was located on the deep face of the common digital flexor tendon just proximal to the metatarsophalangeal articulations and it detached the pulvinar branch and most of the digital arteries.

\section{R. Pulvinaris:}

The pulvinar branch (Fig.6/21) arose from the plantar arch. In five specimens it was given from the A. digitalis III lateralis and entered medial aspect of the metatarsal pad (Fig.6/i) where it ramified into 34branches. 


\section{Aa. digitales:}

Each digit was supplied by two arteries medial and lateral, except the 1st digit was supplied by single artery extending on its plantar side. All digital arteries arose from the plantar arterial arch except those of the $2^{\text {nd }}$ digit and the lateral artery of the $4^{\text {th }}$ digit.

\section{A. digitalis I:}

The digital I artery (Fig.2, 3and 6/22) arose from the medial side of the plantar arch and extended along the plantar aspect of the first digit.

\section{Aa. digitales II medialis and lateralis:}

The medial (Fig.2, 3,4,5, ,7 and 8 and 6/23) and lateral (Fig.2, $3,4,5,6,7$ and 8/24) digital II arteries originated by the bifurcation of the medial dorsal metatarsal artery and extended along the corresponding aspect of the second digit.

\section{A. digitalis III medialis:}

The medial digital III artery (Fig. 3, 4,5,6,7 and 8/25) was detached independently from the the plantar arch. It passed through the medial intertrochlear notch (Fig.2 and 3 /j) deep to the metatarsal pad, giving fine twigs to this pad then extended along the medial aspect of the $3^{\text {rd }}$ digit.

\section{A.digitalis III lateralis and A. digitalis IV medialis:}

The lateral digital III artery (Fig.3, 4,5,6,7 and 8and 6/26) and the medial digital IV artery (Fig.2, 3, 4,5,7 and 8/27) originated by common stem from the plantar arch. This stem passed through the lateral intertrochlear notch (Fig.2 and $3 / \mathrm{k}$ ) deep to the metatarsal pad, giving 
fine twigs to this pad then bifurcated to give the latter two vessels that extended along the lateral aspect of the $3^{\text {rd }}$ digit and the medial side of the $4^{\text {th }}$ digit respectively.

\section{A.digitales IV lateralis:}

The lateral digital IV artery (Fig., 3, 4, 5, 6, and 8/28) arose from the lateral plantar metatarsal artery just before it joins the plantar arch, but In four specimens it was given from the latter arch.It descended alongside the lateral aspect of the $4^{\text {th }}$ digit.

Along thier course the digital arteries gave off fine branches that distributed dorsally to the digital extensor tendons and plantarly to the digital flexor tendons. It is to add that transverse anastomotic branches (Fig. 3, 6, and 7/29) were observed between the medial and lateral digital arteries of the same digit on both dorsal and plantar aspects just distal to the interphalangeal articulations. The digital arteries of each digit were also communicated at the end of the digit, on the plantar aspect of the $3^{\text {rd }}$ phalanx (Fig. 3, 6/q) forming a sort of a terminal arch (Fig. 3, 4/30).

The arterial supply of the interdigital (foot) web was achieved through numerous transverse rami (Fig.4, 8/31) arising from the A.digitalis II lateralis and Aa. digitales III medialis and ramified throughout the tela interdigitalis medialis (Fig.4, 5,7 and 8/n), Similar branches arose from A. digitalis III lateralis and A.digitalis IV medialis and arborized in the tela interdigitalis lateralis (Fig.4,5,7 and 8/o). These rami were anastomosed forming a plentiful arterial rete that distributed allover the foot web. Moreover a longitudinal branch (Fig.4, 5, 7 and 8/32) was detached from A.digitalis IV medialis and extended distally across the tela interdigitalis lateralis towards its free margin. 


\section{Legend for the figures}

1. A.poplitea

2. A. tibialis cranialis

3. Rete tibiotarsale

4. A.fibularis

5. A.fibularis profundus

6. A.fibularis superficialis

7. A.metatarsea dorsalis communis

8. A.metatarsi dorsalis medialis

9. A.metatarsi dorsalis lateralis

10. A.tarsea plantaris medialis

11. A.tarsea plantaris lateralis

12. R.ascendens medialis

13. R.ascendens lateralis

14. A. suralis lateralis

15. R.medialis of $\mathbf{1 3}$

16. R.lateralis of $\mathbf{1 3}$

17. A.metatarsea plantaris medialis

18. A.metatarsea plantaris lateralis

19. Rr.communicans

20. Arcus plantaris

21. R. Pulvinaris

22. A. digitalis I

23. Aa. digitalis II medialis

24. Aa. digitalis II lateralis

25. A. digitalis III medialis
26.A.digitalis III lateralis

27.A.digitalis IV medialis

28.A.digitales IV lateralis

29.anastomotic branches

30.Arcus terminalis

31.Transverse branches

32.Longitudinal branch

a) Distal interosseous foramen

b) Tibiotarsus

c) Fibula

d) Tarsus

e) Tarsometatarsus

f) Proximal vascular foramen

g) Metatarsophalangeal articulation

h) Distal vascular foramen

i) Pulvinus metatarsalis.

j) Medial intertrochlear notch

k) Lateral intertrochlear notch

l) Common digital extensor tendon

m) Superficial digital fLexor tendon

n) Tela interdigitalis medialis

o) Tela interdigitalis lateralis

p) Pulvinus digitalis

q) Phalanx ungualis (terminalis)

r) Nn. Metatarseae dorsales. 


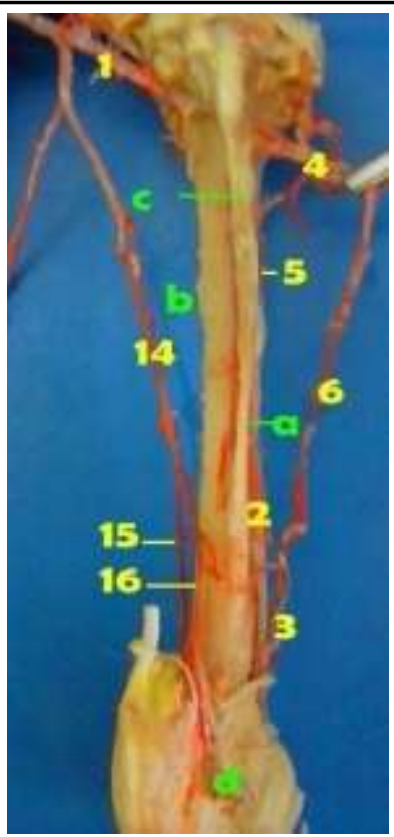

Fig. (1): A photograph of the right leg region of the duck showing the arteries forming the Rete tibiotarsale (lateral view).

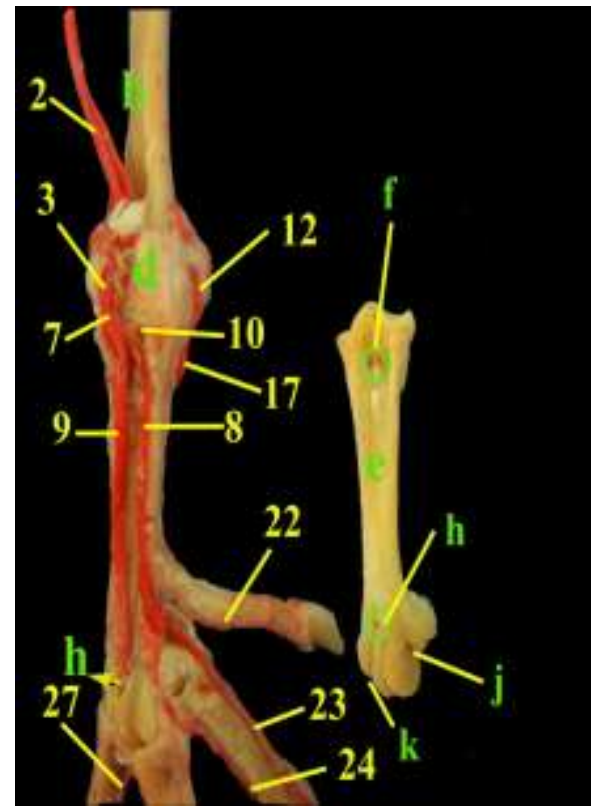

Fig. (2): A photograph showing arteries of the right shank and tibiotarsus of the duck (dorsomedial view) 


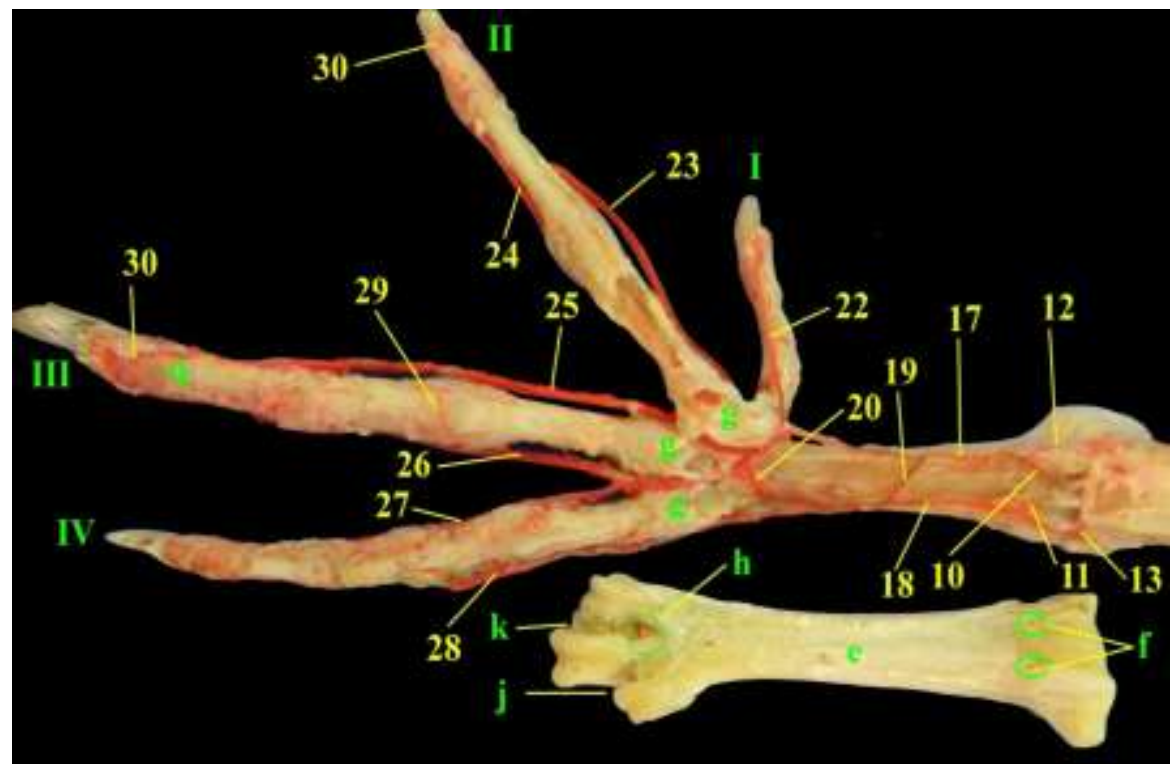

Fig. (3): A photograph showing arteries of the right shank and foot and tibiotarsus of the duck (plantar view). The digital flexor tendons were removed.

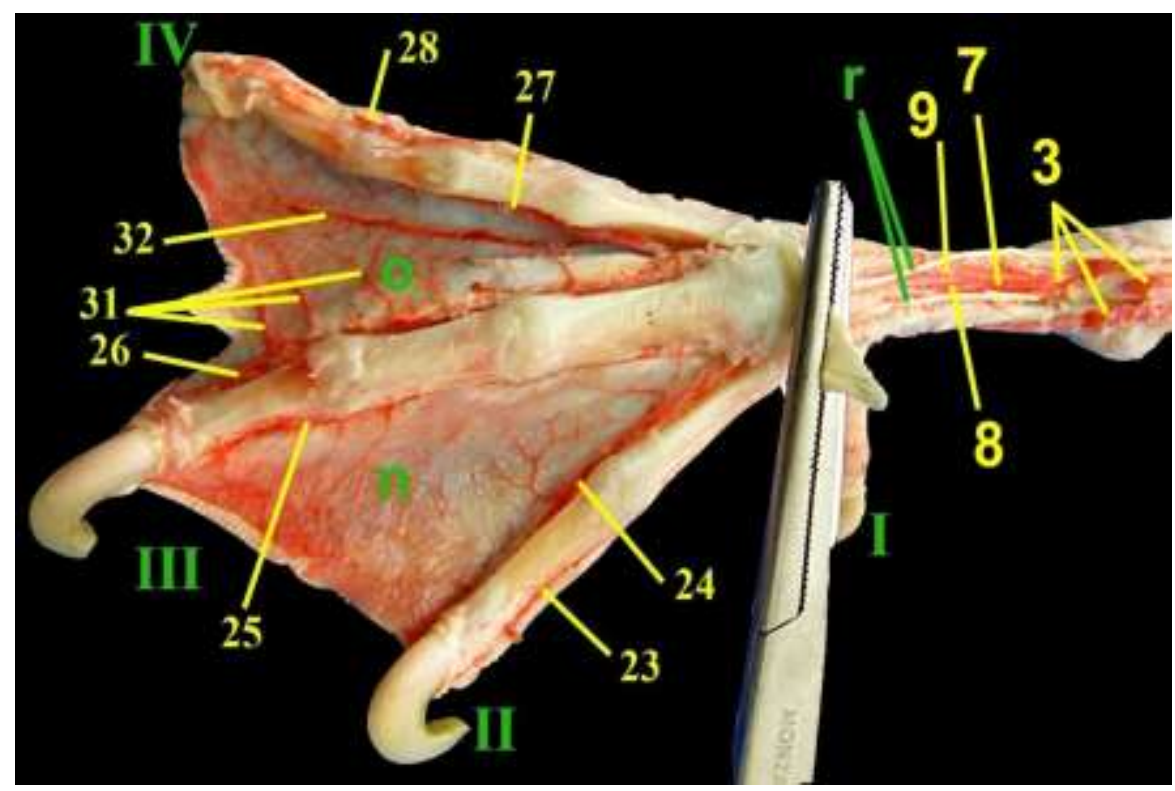

Fig. (4): A photograph showing the arteries of the right shank and foot of the duck (dorsomedial view). The common digital extensor tendon was reflected. 
Farag, F.M.M.

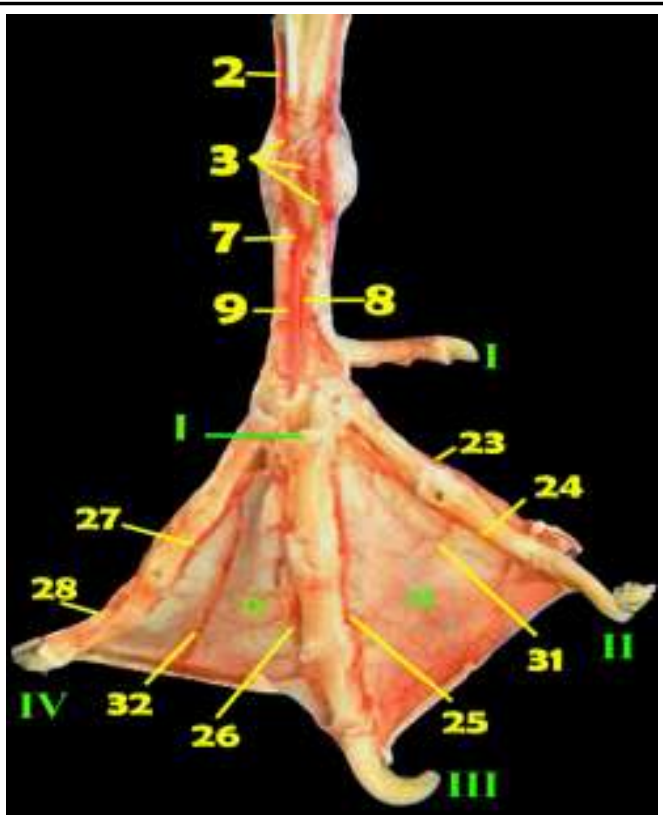

Fig. (5): A photograph showing the arteries of the shank and foot of the right pelvic limb of the duck (dorsal view). The common digital extensor tendon was removed.

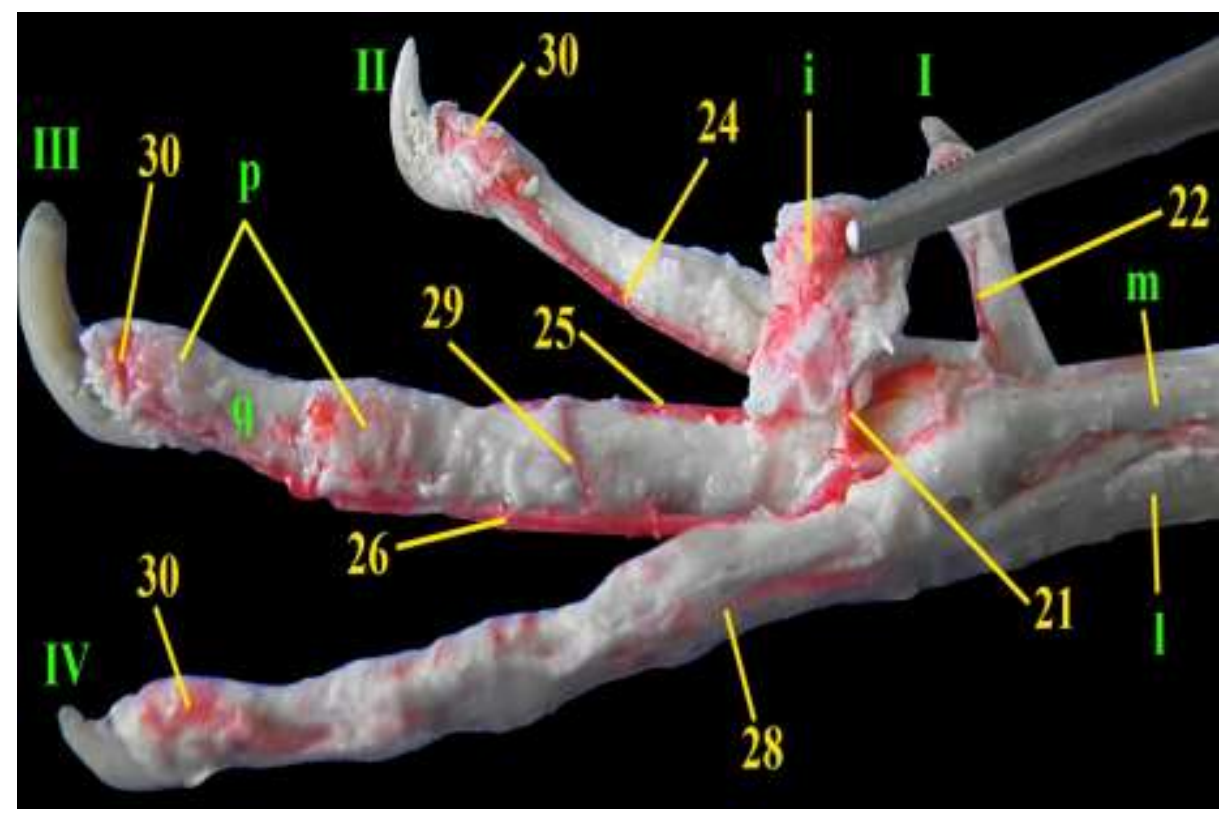

Fig. (6): A photograph showing the Arteries of the right foot (lateral view). 


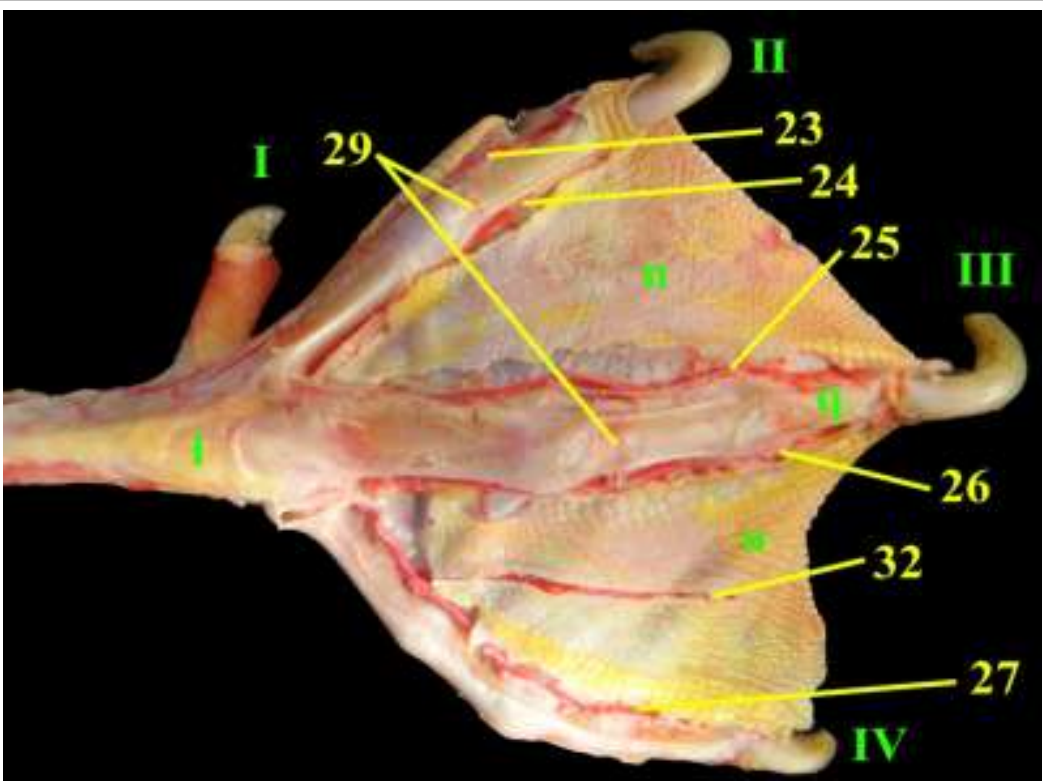

Fig. (7): A photograph showing the arteries of the right foot (dorsal view of dissected specimens).

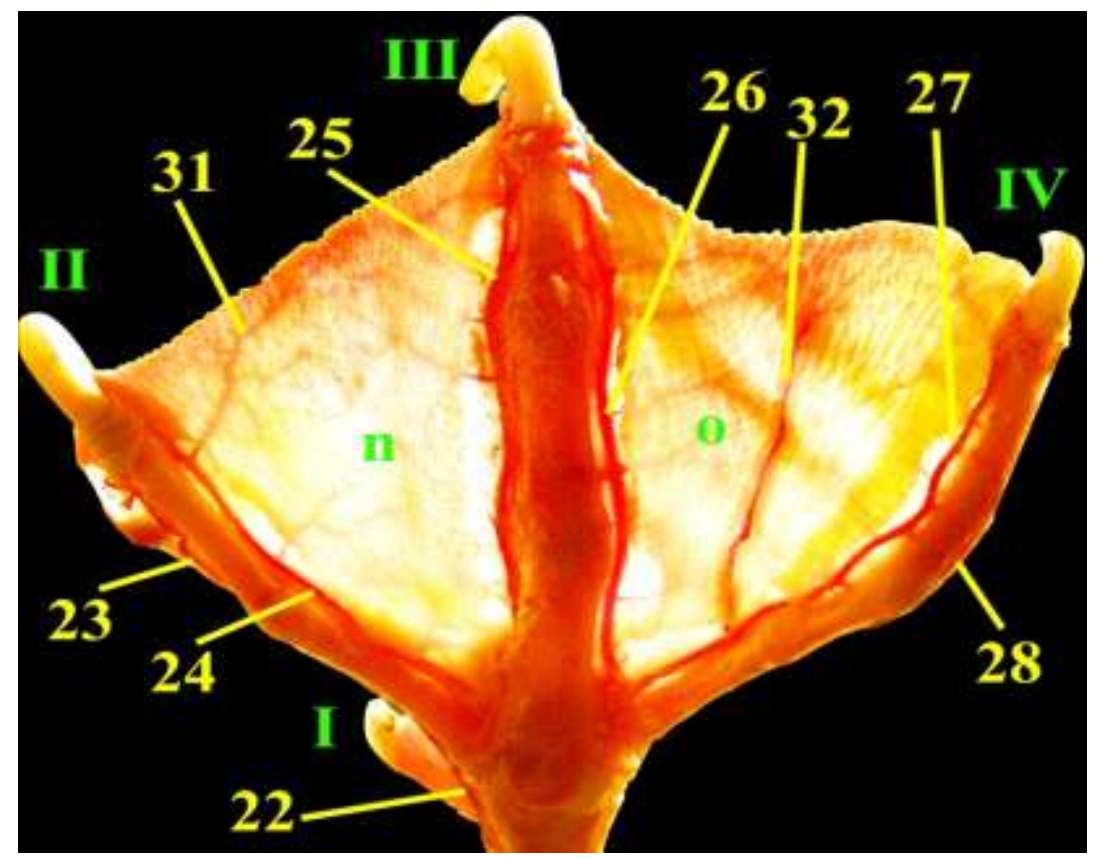

Fig. (8): A photograph showing the arteries of the right foot (dorsal view with light background). 


\section{DISCUSSION}

The present study recorded that the cranial tibial artery was the direct continuation of the popliteal artery in the distal portion of the leg and foot. The cranial tibial artery continued distally until it reached the flexor surface of the hock joint where it continued as the common dorsal metatarsal artery, a result resembles that demonastrated by Mcleod et al. (1964), Baumel (1975), Nickel et al.(1977) in the domestic fowl and ElNahla et al.(2010) in the ostrich. Can et al., (2010) in the Japanese quail agreed to the previous result but did not mention the common dorsal metatarsal artery in their result. Koch (1973) in the domestic fowl stated that the cranial tibial artery was divided proximal to the tarsal joint into two branches, which supplied the toes.

The present work stated that the collateral branches arising from the distal third of the cranial tibial artery, deep fibular, superficial fibular and lateral sural arteries in addition to some closely related veins formed the Rete tibiotarsale. Similar observations were recorded by Fitzgerald (1969) in the coturnix quail, Midtgard (1981) in the different birds and Dursun (2002) in the domestic birds. Nickel et al. (1977) in the domestic birds named this vascular net as the rete tarsometatarsicus which was formed by the joining of A.tibialis caudalis, A.tibialis medialis and A.tibialis lateralis. Baumel (1975), El-Gammal (2012) and Swielim et al. (2012) did not mentioned the fibular and lateral sural arteries as a component of this rete in the domestic fowl and added that it was differentiated into two retae; Rete tibialis cranialis, proximal to the tarsal joint and rete tarsi dorsalis distal to this joint. 
The present investigations revealed that the common dorsal metatarsal artery constituted the distalward continuation of the cranial tibial artery after traversing the Rete tibiotarsale. It gave of the Aa. tarseae plantares then gave rise to the medial and lateral dorsal metatarsal arteries. On the other hand Mcleod et al. (1964), Baumel (1975), Nickel et al.(1977), Baumel et al. (1993), El-Gammal (2012) and Swielim et al. (2012) in the domestic fowl and El-Nahla et al. (2010) in the ostrich mentioned that the common dorsal metatarsal artery was terminated at the base of the digits by forming the digital arteries. Mcleod et al. (1964) in the domestic fowl named this vessel as the great metatarsal artery. It may be added that the lateral dorsal metatarsal artery in the duck pierced through the dital vascular foramen of the tarsometatarsus to join the plantar arch, in similitude to the distal perforating branch described by Ghoshal (1975) in the domestic animals.

In the domestic duck, the lateral and medial plantar tarsal arteries were given off from the common dorsal metatarsal artery on the dorsal aspect of the proximal end of the tarsometatarsus similar to that recorded by Baumel (1975), Baumel et al. (1993) in the domestic fowl and El-Nahla et al., (2010) in the ostrich. On the other hand, El-Gammal (2012) and Swielim et al. (2012) mentioned that in the domestic fowl, the corresponding vessels arose from the Rete tarsi dorsalis. Nickel et al., (1977) in the domestic fowl mentioned that the latter two vessels arose as single artery that soon divided into the lateral and medial branches and named this vessel as the plantar metatarsal artery a result which observed in eight specimens only in the present study. It is to add that each of Kafrelsheikh Vet. Med. J. Vol. 11 No. 1 (2013) 
these vessels pierced through the corresponding proximal vascular foramen and this behaviour could be matched favourably with the proximal perforating branch mentioned by Ghoshal (1975) in the domestic animals. On reaching the plantar aspect each of these vessels was soon divided into two branches; an ascending and a descending branch the same as recorded by El-Nahla et al. (2010) in the ostrich and El-Gammal (2012) and Swielim et al. (2012) in the domestic fowl.

The current investigation had revealed that each digit was supplied by two arteries medial and lateral, except the 1st digit was supplied by single artery and all the digital arteries arose from the plantar arterial arch except those of the $2^{\text {nd }}$ digit and the lateral artery of the $4^{\text {th }}$ digit arising from the medial dorsal metatarsal and lateral plantar metatarsal arteries respectively. El-Gammal (2012) and Swielim et al. (2012) revealed that the plantar arterial arch gave off the medial and lateral digital I, medial digital II, medial digital III and the lateral digital IV arteries, the medial dorsal metatarsal artery detached the lateral digit II artery, while the lateral dorsal metatarsal artey gaves both lateral digital III artery and medial digital IV artery. In Ostrich (El-Nahla et al., 2010) the digital arteries were mentioned to be four in number; two arose from the common dorsal metatarsal artery to run on the abaxial surface of the third and fourth digits and the remaining two arose from the plantar metatarsal artery and the common dorsal metatarsal artery to run on the abaxial surface of the fourth and third digits, respectively. Nickel et al., (1977) in the domestic fowl described that the first, second and fourth digits are supplied by one digital artery for each, whereas the third digit $\overline{\text { Kafrelsheikh Vet. Med. J. Vol. } 11 \text { No. } 1 \text { (2013) }}$ 
was supplied by two digital arteries. The digital arteries of the first and second digits and the medial digital artery of the third digit originated from the plantar arterial arch, whereas the lateral digital artery of the third digit and the digital artery of the fourth digit arose directly from the lateral metatarsal artery. Baumel (1975) and Baumel et al., (1993) in the domestic fowl reported that the proper digital arteries to the first and second digits came either from the plantar arch or directly from the plantar metatarsal artery, while the digital arteries to the third and fourth digits arose from the dorsal metatarsal arteries.

The plenty of arterial supply to the interdigital (foot) web of the duck as revealed in the present study explained its thermoregulatory function as recorded by Kardong (2008) who mentioned that retia mirabilia in the legs and feet of birds transfer heat from the outgoing (hot) blood in the arteries to the incoming (cold) blood in the veins. The effect of this biological heat exchanger is that the internal temperature of the feet is much closer to the ambient temperature, thus reducing heat loss.

According to the current investigation the metatarsal pad was supplied by one main branch, the R. pulvinaris arising from either the plantar arch or the A. digitalis III lateralis, According to Baumel (1975, 1993) and Nickel et al., (1977) in the domestic fowl, the pulvinar artery arose from the common dorsal metatarsal artery and passed through the distal foramen of the tarsometatarsus. It is prudent to ligate this R.pulvinaris before surgical removal of fibriscess swelling of the metatarsal pad in the duck. 


\section{REFERENCES}

- Baumel, J. J. (1975): Aves Heart and Blood Vessels. In: Getty, R., Sisson, S. and Grossman's, J. D.The Anatomy of the Domestic Animals, $5^{\text {th }}$ edition, W. B. Saunders Company. Philadelphia, PA, USA. Vol. (2): 1993-1996 and 2006-2009.

- Baumel, J. J., King, A.S., Lucas, A.M. Breazile, J.E. and Evans, H.E. (1993): Systema Cardiovasculare. In: Nomina Anatomica Avium. (J. J. Baumel, A. S. King, A. M. Lucas, J. E. Breazile, and H. E. Evans, eds). London, UK: Academic Press.360-501.

- Can, M O.Z. and Ozdemir, D. (2010): Arterial Vascularization of the Hind Limb Muscles in the Japanese Quails (Countrix countrix japonica). Journal of Animal and Veterinary Advances. 9 (17): 2265-2270.

- Cooper J.E. (2002): Birds of Prey: Health and Disease. Oxford: Blackwell Science.

- Dursun, N., (2002): Evcil Kuslarin Anatomisi. Ankara Universitesi Veteriner Fakultesi, Ders Kitaplari, Ankara Universitesi Basimevi, Ankara.

- El-Gammal,S.(2012): Anatomical studies on the blood supply of the pelvic limb of the chicken, with special reference to the renal portal system and renal elimination of some drugs. Thesis M.V.Sc. Fac. Vet. Med. Cairo Univ.

- El-nahla, S. M., El-mahdy, T., Abbott, L. C. and Hassan, S A.M. (2010): The Arterial Supply of the Pelvic limb of the Adult Ostrich (Sturthio camelus). Journal of Veterinary Medicine, Anatomia, Histologia, Embryologia.39 (4): 339-354. 
- Fitzgerald, T.C. (1969): The Coturnix Quail, Anatomy and Histology. Iowa State University Press, Ames, Iowa.

- Goshal,N.G.(1975): (Heart and arteries of domestic animals in "Sisson and Grossman" anatomy of domestic animals. $5^{\text {th }}$ edition Vol.1 and 2 reviewed by R. Getty. W.B. SAUNDERS Philadelphia, London.

- Heidenreich M (1997): Birds of Prey: Medicine and Management. Oxford: Blackwell, Wissenschafts-Verlag.

- Kardong, K. (2008): Vertebrates: Comparative anatomy, function, evolution,(5th ed.). Boston: McGraw-Hill.

- Koch, T. (1973): Anatomy of Chicken and Domestic Birds. Translated From the German manuscript by B. H. Skold and L. Devries. Ames, IA, USA: The Iowa State University Press. 111-138.

- Mcleod, W. M., Trotter, D. M. and Lumb, J. W. (1964): Avian Anatomy. Minneapolis, Mn, USA: Burgess Publishing Company. 76-87.

- Midtgard, U. (1981): Patterns in the Blood Vascular System in the Pelvic Limb of Birds. Journal of Zoology.196 (4): 544-567.

- Nickel, R., Schummer, A. and E. Seiferle, E. (1977): Anatomy of the Domestic Birds. Berlin: Verlag Paul Parey. 96-99 and 101-103.

- Routh A. (2000): Veterinary care of the mute swan. In Practice; 22: 426-43.

- Swielim, G.A., Khlifa, E.F. and El-Gammal, S.M. (2012): Anatomical studies on the arterial blood supply of the pelvic limb of chicken. SCVMJ, XVII (2). 


\section{المدد الدموي الثرياني للقدم في البط المستأنس}

أجري هذا لدراسة البحث المدد الدموي للقدم لعدد عثره من البط المستأنس صحيحة ناضجة من السلالات البلدية يتراوح أوزانها مابين اثثين ونصف كيلوجرام إلى ثلاثة و نصف كيلو جرام.

عولجت العينـات بعد ذبحها وإستنزافها للتخلص مـن بقايـا الدم فى أوعيتها الدمويـة، بحقنها بمحلول اللاتكس نيوبرين(السائل المطاطي اللبني) الملون باللون الأحمر اللشرايين ثم حفظت في خليط من الفورمالين 10\%، الفينول 4\% والجليسرين 1\% وتم تشريحها بدقة بعد ثلاثة أيام. وقد تبين من البحث أن المدد الدموي الثرياني لمنطقة القدم ينم بواسطة الثريان القصبي الأمامي. وأن شرايين منطقه القدم تتقسم إلى مجموعتين : مجموعه ظهريه وأخرى اخمصيه. وقد تم وصف منشأ، مسار و نوزيعات الثرايين بمنطقه القدم بدقة وتم ضبط المسميات على لائحة المصطلحات التشريحية البيطرية الدولية للطيور لسنة 1993 في تسمية الثرايين. تحتوى الدراسة على رسومات توضيحية، وذلك لتوضيح النتائج. كما نوقتنت النتائج المناحة في الدراسة مع ما تم الحصول علية في الأعمال السابقة في الدواجن والطيور المستأنسة. 